\title{
First Record of Two Urostyloid Ciliates (Spirotrichea: Urostylida: Urostyloidea) from Brackish Water in Korea
}

\author{
Jung Min Choi, Ji Hye Kim, Mann Kyoon Shin* \\ Department of Biological Science, University of Ulsan, Ulsan 680-749, Korea
}

\begin{abstract}
Two urostyloid ciliates, collected from brackish water in Korea, were identified as Diaxonella pseudorubra pseudorubra (Kaltenbach, 1960) Berger, 2006 and Pseudokeronopsis flava (Cohn, 1866) Wirnsberger, Larsen and Uhlig, 1987. The description was based on living, protargol impregnated specimens. These species are described as follows: Diaxonella pseudorubra pseudorubra: body size in vivo $145-230 \times 40-60 \mu \mathrm{m}$, elongated ellipsoidal in shape. Cytoplasm reddish and flexible. Adoral zone of membranelles occupied $30-40 \%$ of the body; composed of 33-44 membranelles; 1-3 frontoterminal cirri, 1-4 frontal row cirri, 4-6 buccal cirri, 6-10 transverse cirri. Midventral rows composed of 14-24 cirri, four left marginal rows, one right marginal row. Two kinds of cortical granules; the larger one is yellowish and the smaller one is reddish. Pseudokeronopsis flava: body size in vivo $150-210 \times 30-45 \mu \mathrm{m}$, elongated ellipsoidal shape. Cytoplasm yellowish and flexible. Adoral zone of membranelles occupied $25-30 \%$ of body; composed of 44-58 membranelles in number. Frontal cirri forming bicorona composed of 5-7 cirral pairs, 2-3 frontoterminal cirri, one buccal cirrus, and 2-3 transverse cirri. Midventral rows composed of 18-33 cirri, 34-53 left marginal cirri, and 40-58 right marginal cirri. Two kinds of cortical granules; the larger one is colorless and "blood-cell-shaped," and the smaller one is yellowish. Diaxonella pseudorubra pseudorubra is different from the most similar subspecies, D. pseudorubra pulchra, in cytoplasmic color and number of midventral cirri. Pseudokeronopsis flava is different from its most similar congeners in pigment granular color, number of bicorona, number of midventral cirri, and position of the contractile vacuole.
\end{abstract}

Keywords: Diaxonella, Pseudokeronopsis, hypotrichs, redescription, estuary, brackish water, morphology

\section{INTRODUCTION}

The urostyloid ciliates are composed of a large group of hypotrichs, sensu lato, which belong to the superfamily Urostyloidea, and more than 2,000 species have been described (Berger, 2006; Lynn, 2008). Since the superfamily Urostyloidea was established by Bütschli (1889), its definition has been improved as usually having an ellipsoidal, middle to large sized body and a midventral complex between the marginal rows (Corliss, 1979; Lynn and Small, 2002; Berger, 2006; Lynn, 2008). The systematics of genus Diaxonella has a comparatively complex history, including many synonyms (Jankowski, 1979; Foissner, 1987; Oberschmidleitner and Aescht, 1996; Berger, 2006; Shao et al., 2007). Diaxonella pseudorubra (Kaltenbach, 1960) was a monotypic species of the genus Diaxonella, but three subspecies, D. pseudoru- bra pseudorubra, D. pseudorubra polystylata, and D. pseudorubra pulchra, have been recognized recently by Berger (2006). The genus Pseudokeronopsis includes 10 species and is usually found in marine environments (Song et al., 2002, 2004, 2006). Most Pseudokernopsis species have cortical granules colored red, yellow, or orange-yellow, which can be used to distinguish the species. In this study, we provide morphological redescriptions and variations in two urostyloids from Korea.

\section{MATERIALS AND METHODS}

\section{Sample collection and enrichment}

Diaxonella pseudorubra pseudorubra and Pseudokeronopsis flava were collected from brackish waters in Korea. Diaxo-

\footnotetext{
(c) This is an Open Access article distributed under the terms of the Creative Commons Attribution Non-Commercial License (http://creativecommons.org/ licenses/by-nc/3.0/) which permits unrestricted non-commercial use, distribution, and reproduction in any medium, provided the original work is properly cited.
}

\author{
*To whom correspondence should be addressed \\ Tel: 82-52-259-2396, Fax: 82-52-259-1694 \\ E-mail: mkshin@ulsan.ac.kr
}


nella pseudorubra pseudorubra: (October, 2010; salinity $2 \%$ ) downstream of the sewage treatment plant (N34 $55^{\prime} 23^{\prime \prime}$, E128 $07^{\prime} 07^{\prime \prime}$ ) located in Sadeung-dong, Sacheon-si, Gyeongsangnam-do. The water samples including the ciliates were collected with twigs, leaves, wood, and mud. P. flava: (January, 2010; salinity 20\%o) in the Soesokkak estuary (N33 $15^{\prime \prime} 7.19^{\prime \prime}$, E126 $\left.37^{\prime 2} 24.59^{\prime \prime}\right)$, Seogwipo-si, Jeju-do. The specimens were transferred to a Petri dish ( $87 \mathrm{~mm}$ in diameter) or a cell culture dish ( $150 \mathrm{~mm}$ in diameter). These ciliates have been cultured at room temperature in the laboratory with collected water, enriched with dried wheat grain to supply fungal and bacterial nutrients

\section{Morphological observation}

The morphology of living specimens was observed under low $(50-400 \times)$ and high $(1,000 \times$; immersion oil) magnifications using a light microscope with a DIC device (Axio Imager A1; Carl Zeiss, Oberkochen, Germany) and their images were captured using a CCD camera (Axio Cam MRc; Carl Zeiss). The infraciliatures were observed after impregnation using the protagol method (Wilbert, 1975; Foissner, 1992). Terminology and taxonomic classification are accord- ing to Berger (2006) and Lynn (2008).

\section{SYSTEMATIC ACCOUNTS}

Order Urostylida Jankowski, 1979

Superfamily Urostyloidea Bütschli, 1889

Family Holostichidae Fauré-Fremiet, 1961

Genus ${ }^{1 *}$ Diaxonella Jankowski, 1979

\section{2*Diaxonella pseudorubra pseudorubra}

(Kaltenbach, 1960) (Tables 1, 2, Figs. 1-3)

Keronopsis pseudorubra Kaltenbach, 1960 (cited from Berger, 2006: 470).

Keronopsis rubra Jerka-Dziadosz and Janus, 1972: 249.

Diaxonella trimarginata Jankowski, 1979: 83; Oberschmidleitner and Aescht, 1996: 21; Shao et al., 2007: 25.

Holosticha pseudorubra: Foissner, 1987: 225; Berger, 2001: 44.

Diaxonella pseudorubra pseudorubra: Berger, 2006: 468.

Description. General morphology and behavior: Body

Table 1. Morphometric data of Diaxonella pseudorubra pseudorubra

\begin{tabular}{|c|c|c|c|c|c|c|c|c|c|}
\hline Characteristics & Method & Mean & Min & Max & Med & SD & SE & $\mathrm{CV}$ & $\mathrm{n}$ \\
\hline \multirow[t]{2}{*}{ Body length $(\mu \mathrm{m})$} & $\mathrm{L}$ & 171.5 & 145 & 230 & 167.5 & 22.0 & 4.9 & 12.8 & 20 \\
\hline & $\mathrm{S}$ & 149.7 & 117 & 180 & 151.5 & 18.7 & 4.2 & 12.5 & 20 \\
\hline Body width $(\mu \mathrm{m})$ & $\mathrm{L}$ & 47.8 & 40 & 60 & 49.0 & 5.4 & 1.2 & 11.4 & 20 \\
\hline & $\mathrm{S}$ & 55.6 & 42 & 67 & 56.0 & 7.4 & 1.7 & 13.4 & 20 \\
\hline \multirow[t]{2}{*}{ Body length/Body width } & $\mathrm{L}$ & 3.6 & 3 & 4 & 3.7 & 0.4 & 0.1 & 10.1 & 20 \\
\hline & $\mathrm{S}$ & 2.7 & 2 & 3 & 2.7 & 0.3 & 0.1 & 10.6 & 20 \\
\hline & $\mathrm{S}$ & 61.9 & 54 & 71 & 61.5 & 5.0 & 1.1 & 8.1 & 20 \\
\hline \multirow[t]{2}{*}{ Body length/length of AZM } & $\mathrm{L}$ & 3.0 & 2 & 4 & 3.0 & 0.3 & 0.1 & 11.4 & 20 \\
\hline & $\mathrm{S}$ & 2.4 & 2 & 3 & 2.4 & 0.2 & 0.0 & 6.8 & 20 \\
\hline AMs, number & $\mathrm{S}$ & 38.5 & 33 & 44 & 38.0 & 3.2 & 0.7 & 8.2 & 20 \\
\hline BC, number & $\mathrm{S}$ & 5.3 & 4 & 6 & 5.0 & 0.6 & 0.1 & 10.8 & 20 \\
\hline FC, number & $\mathrm{S}$ & 4.1 & 3 & 5 & 4.0 & 0.4 & 0.1 & 9.7 & 20 \\
\hline FTC, number & $\mathrm{S}$ & 2.0 & 1 & 3 & 2.0 & 0.4 & 0.1 & 17.7 & 17 \\
\hline TC, number & $\mathrm{S}$ & 7.9 & 6 & 10 & 8.0 & 1.0 & 0.2 & 13.2 & 20 \\
\hline PTC, number & $\mathrm{S}$ & 2.0 & 2 & 2 & 2.0 & 0.0 & 0.0 & 0.0 & 20 \\
\hline MVC (pair), number & $\mathrm{S}$ & 19.1 & 14 & 24 & 19.0 & 2.9 & 0.7 & 15.0 & 15 \\
\hline RMC, number & $\mathrm{S}$ & 41.4 & 30 & 50 & 42.0 & 5.6 & 1.3 & 13.4 & 17 \\
\hline $\mathrm{LMC}_{1}$, number & $\mathrm{S}$ & 30.1 & 21 & 38 & 29.0 & 4.8 & 1.3 & 16.1 & 15 \\
\hline $\mathrm{LMC}_{2}$, number & $\mathrm{S}$ & 25.7 & 20 & 33 & 25.0 & 3.5 & 0.9 & 13.6 & 15 \\
\hline $\mathrm{LMC}_{3}$, number & $\mathrm{S}$ & 21.6 & 18 & 28 & 20.0 & 3.2 & 0.8 & 14.9 & 15 \\
\hline $\mathrm{LMC}_{4}$, number & $\mathrm{S}$ & 11.1 & 4 & 15 & 12.0 & 3.3 & 0.8 & 29.5 & 15 \\
\hline DKs, number & $\mathrm{S}$ & 3.3 & 3 & 4 & 3.0 & 0.5 & 0.1 & 14.5 & 13 \\
\hline
\end{tabular}

Min, minimum; Max, maximum; Med, median; CV, coefficient of variation in \%; $n$, population size; L, live specimens; $\mathrm{S}$, stained specimens; AZM, adoral zone of membranelles; BC, buccal cirrus; FC, frontal cirri; FTC, frontoterminal cirri; FRC, frontal row cirri; TC, transverse cirri; PTC, pretransverse cirri; MVC, midventral cirri; RMC, right marginal cirri; LMC, left marginal cirri; DK, dorsal kineties.

Korean name: ${ }^{1 *}$ 쌍열충속, ${ }^{2 *}$ 붉은쌍열충 
Jung Min Choi, Ji Hye Kim, Mann Kyoon Shin

Table 2. Comparisons of Diaxonella pseudorubra pseudorubra which has different names

\begin{tabular}{|c|c|c|c|c|}
\hline Characters & $\begin{array}{c}\text { Diaxonella pseudorubra } \\
\text { pseudorubra }\end{array}$ & D. trimarginata & D. trimarginata & Keronopsis rubra \\
\hline Body length in vivo $(\mu \mathrm{m})$ & $145-230$ & $120-180$ & $95-185$ & - \\
\hline Body length $(\mu \mathrm{m})$ & $117-180$ & 93-198 & $108-200$ & $130-170$ \\
\hline AMs, number & $33-44$ & $31-40$ & $31-42$ & ca. 35 \\
\hline BC, number & $4-6$ & $5-7$ & 5-8 & ca. 5 \\
\hline FC, number & $3-5$ & $2-3$ & Constantly, 4 & ca. 3 \\
\hline FTC, number & $1-3$ & $2-3$ & $1-4$ & - \\
\hline FRC, number & $1-4$ & $4-6$ & $3-5$ & $3-4$ \\
\hline TC, number & $6-10$ & $6-9$ & $7-10$ & ca. 10 \\
\hline MVC (pairs), number & $14-24$ & $18-27$ & $16-29$ & ca. $34 *$ \\
\hline RMC, number & $30-50$ & $34-54$ & $27-51$ & $40-55$ \\
\hline LMR, number & Constantly 4 & $3-4$ & Constantly, 4 & ca. 2 \\
\hline PTC, number & Constantly 2 & 3-4 & $0-4$ & - \\
\hline $\mathrm{Mi}$, shape & Spherical & Ellipsoidal & Ovoid & - \\
\hline $\mathrm{Mi}$, size (diameter, $\mu \mathrm{m}$ ) & ca. 2.5 & ca. 2.5 & ca. 5 & - \\
\hline UM, intersecting point & Middle & Middle & Posterior & Middle \\
\hline Position of the last MVC & Posterior half & Posterior & Posterior half & Posterior half \\
\hline Canals in the CV & Absent & Present & Absent & - \\
\hline Data source & Present study & $\begin{array}{c}\text { Oberschmidleitner and } \\
\text { Aescht, } 1996\end{array}$ & Shao et al., 2007 & $\begin{array}{c}\text { Jerka-Dziadosz and } \\
\text { Janus, } 1972\end{array}$ \\
\hline
\end{tabular}

All data are based on protargol-impregnated specimens. AMs, adoral membranelles; BC, buccal cirri; FC, frontal cirri; FTC, frontoterminal cirri; FRC, frontal row cirri; TC, transverse cirri; MVC, midventral cirri; RMC, right marginal cirri; LMR, left marginal row; PTC, pretransverse ventral cirri; Mi, micronucleus; UM, undulating membranes; CV, contractile vacuole.

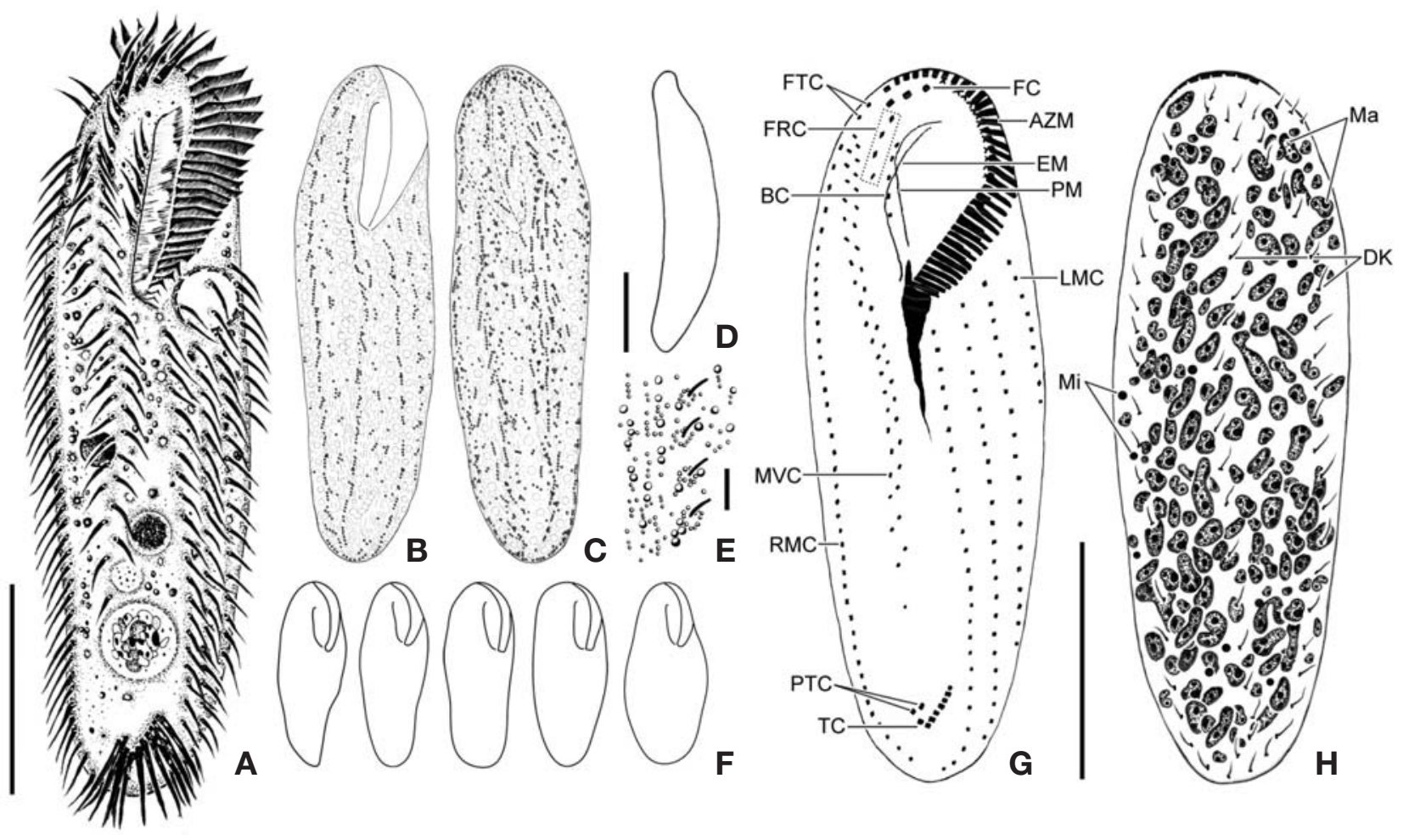

Fig. 1. Diaxonella pseudorubra pseudorubra from live (A-F) and impregnated specimens $(G, H)$. A, Ventral view of a typical individual; B, C, Arrangement of cortical granules on ventral and dorsal sides; D, Flattened lateral view; E, Two kinds of cortical granules on dorsal side; F, Various body shapes; G, Somatic and oral infraciliature of ventral side; $H$, Dorsal kineties and nuclear apparatus. $A Z M$, adoral zone of membranelles; BC, buccal cirrus; DK, dorsal kineties; EM, endoral membrane; FC, frontal cirri; FRC, frontal row cirri; FTC, frontoterminal cirri; LMC, left marginal cirri; Ma, macronuclear nodules; Mi, micronuclei; MVC, midventral cirri; PM, paroral membrane; PTC, pretransverse cirri; RMC, right marginal cirri; TC, transverse cirri. Scale bars: $A, D, G=50 \mu \mathrm{m}, E=5 \mu \mathrm{m}$. 


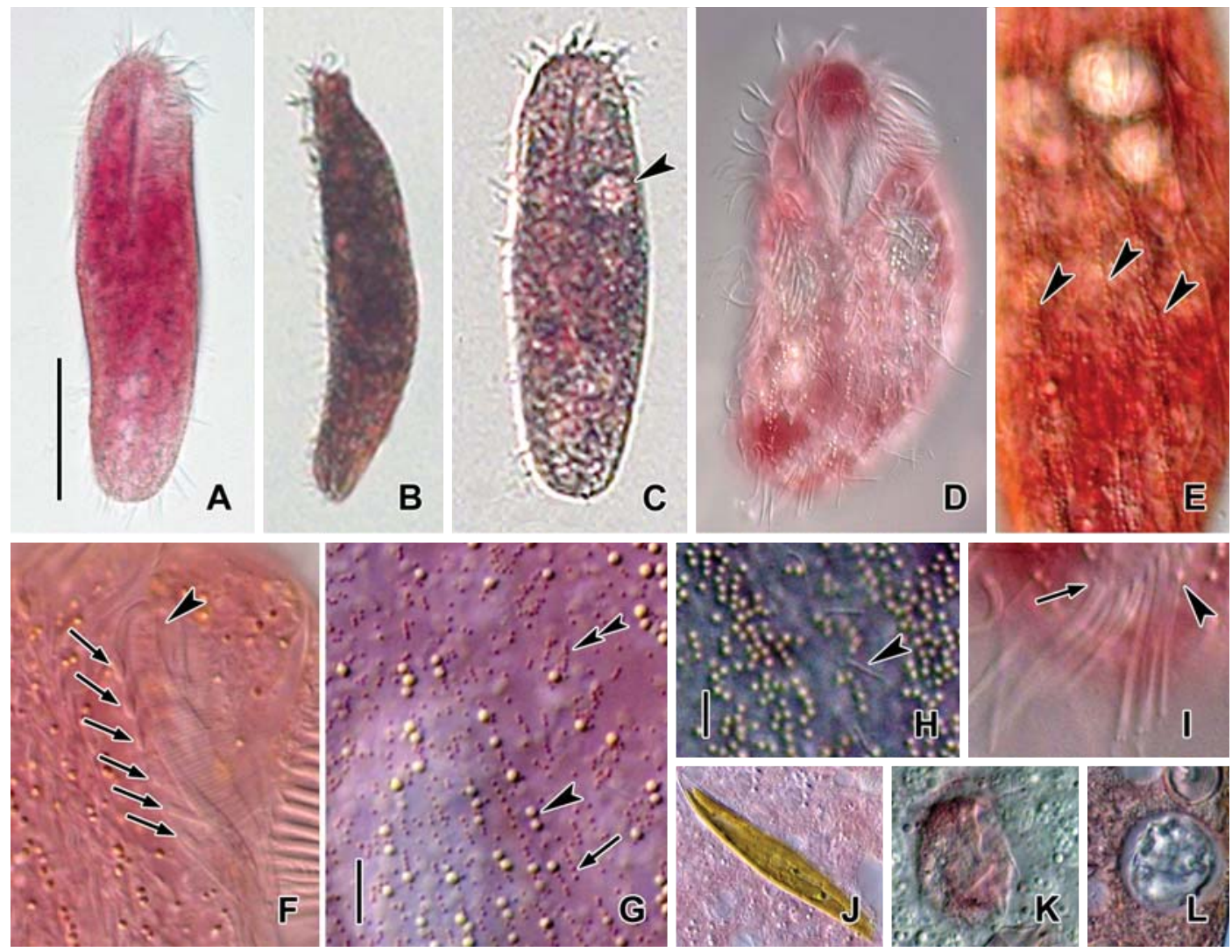

Fig. 2. Photomicrographs of Diaxonella pseudorubra pseudorubra from live specimens. A, Ventral view of a typical individual; $B$, Flattened lateral view; C, Contractile vacuole (arrowhead); D, Somatic ciliature of the ventral side; E, Arrangement of cortical granules on the ventral side (arrowheads); F, Buccal cirri (arrows) and undulating membranes (arrowhead); G, Patterns of cortical granules: larger (arrowhead) and smaller (arrow), arrangement around dorsal bristle of smaller cortical granules (double arrowhead); H, Dorsal bristles (arrowhead); I, Pretransverse cirri (arrow) and transverse cirri (arrowhead); J-L, Various food vacuoles; J, Diatom Pleurosigma sp.; K, Aspidisca sp.; L, Small particle of wheat grain. Scale bars: A=50 $\mu \mathrm{m}, \mathrm{G}, \mathrm{H}=5 \mu \mathrm{m}$.

size $145-230 \times 40-60 \mu \mathrm{m}$, usually about $170 \times 40 \mu \mathrm{m}$, length: width ratio about $4: 1$ on average in live specimens. Body shape elongated and ellipsoid with rounding at both ends (Figs. 1A, 2A, 3A), dorsoventrally flattened about $2: 1$, ventral side slightly concave, dorsal side convex (Figs. 1D, 2B). Cytoplasm reddish to wine color and flexible (Fig. 2D). Single contractile vacuole spherical and above the mid-body near the left margin (Figs. 1A, 2C). Locomotion usually crawling on substrate. Omnivorous feeding (Fig. 2J-L).

Buccal field and oral infraciliature: Adoral zone of membranelles occupies 30-40\% of body length (Figs. 1G, 3A), distal to proximal continuously semicircular, consists of 3344 adoral membranelles (Fig. 3B), widest membranelle about $10 \mu \mathrm{m}$ in length. Buccal area narrow and rather deep. Undulating membranes intersecting to half of the membranes, endoral membrane slightly curved and longer, paroral membrane anteriorly curved and shorter, distal end of paroral beyond endoral, about $45 \mu \mathrm{m}$ in total length (Figs. 1G, 3B).
Somatic infraciliature: Usually, four frontal cirri slightly enlarged, lying on front of the anterior region but one frontal cirrus near the distal end of the adoral zone of membranelles (Figs. 1G, 3C), about $17 \mu \mathrm{m}$ long. One to three frontoterminal cirri located on the right side of frontal cirri, about $12 \mu \mathrm{m}$ long (Fig. 3D). Four to six buccal cirri arranged along paroral membrane, about $8 \mu \mathrm{m}$ long (Figs. 2F, 3B). Inconspicuous, usually four frontal row cirri starting at the same level at the distal end of the paroral membrane and terminating at the same level at intersecting point of the undulating membranes (Figs. 1G, 3E). Midventral complex composed of 14-24 pairs of midventral cirri, continued frontoterminal cirri, arranged in a zigzag pattern, terminating at the posterior half but most cirri separated from others (Figs. 1G, 3G). Six to ten transverse cirri arranged in a J-shape, about $18 \mu \mathrm{m}$ long (Figs. 2I, $3 \mathrm{H})$. Two pretransverse cirri located near right transverse cirrus (Fig. 3H). One right marginal row consisting of 30-50 cirri (Figs. 1G, 3G). Four left marginal rows that gradually 


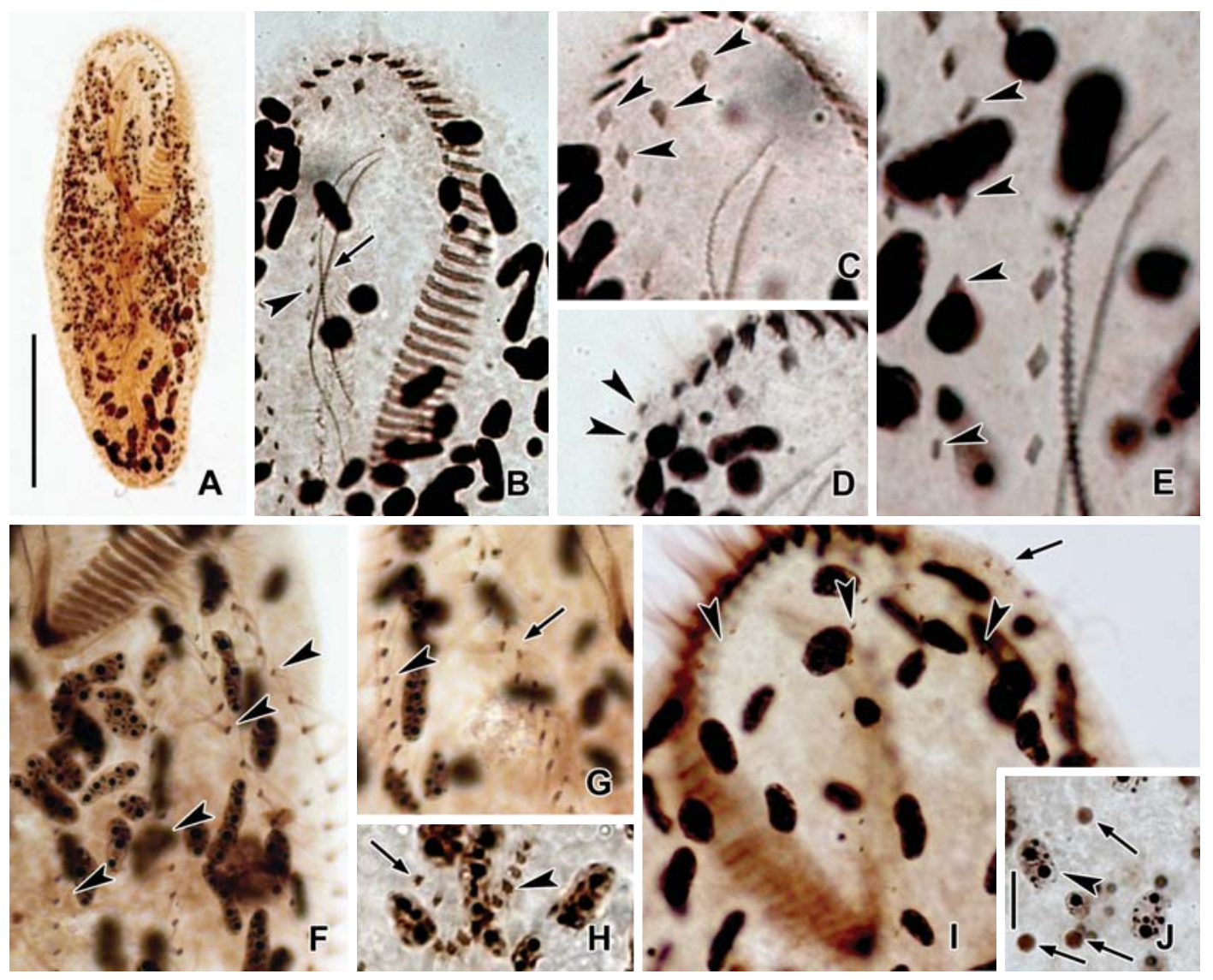

Fig. 3. Photomicrographs of Diaxonella pseudorubra pseudorubra from impregnated specimens. $A$, Ventral view of a typical individual; B, Buccal cirri (arrowhead) and undulating membranes (arrow); C, Four frontal cirri (arrowheads); D, Two frontoterminal cirri (arrowheads); E, Frontal row cirri (arrowheads); F, Four left marginal rows (arrowheads); G, Right marginal row (arrowhead) and midventral complex (arrow); $\mathrm{H}$, Pretransverse cirri (arrow) and transverse cirri (arrowhead); I, Dorsal kineties (arrowheads) and extra dorsal bristles (arrow); J, Macronuclear (arrowhead) and micronuclei (arrows). Scale bars: A=50 $\mu \mathrm{m}, \mathrm{J}=10 \mu \mathrm{m}$.

shorten from right to left composed of 21-38, 20-33, 18-28, and 4-15 cirri, respectively (Figs. 1G, 3F). Three dorsal kineties complete, but some cases of extra dorsal bristles present, bristle about 3-4 $\mu \mathrm{m}$ in length (Figs. 1H, 2H, 3I).

Cortical granules: Two kinds of cortical granules present on both sides and pigmented: larger one greenish yellow about $1 \mu \mathrm{m}$ in diameter, arranged linearly in short groups beside the cirral rows on the ventral side and densely arranged on the dorsal side but loosely around each kineties (Fig. 1B, C). Smaller one red wine colored, about $0.3 \mu \mathrm{m}$ in diameter, scattered around the whole body and arranged linearly in short groups between larger granules or around each cirrus (Figs. $1 \mathrm{E}, 2 \mathrm{G})$.

Nuclear apparatus: Various shaped which elongated ellipsoidal to ovoid macronuclear nodules throughout the whole body, about 120 in number with several nucleoli. Spherical shaped micronuclei scattered body and $2.5 \mu \mathrm{m}$ in diameter
(Figs. 1H, 3A, J).

Distribution. Europe (Austria, Germany, and Poland), Africa (Burundi) and Asia (China, Korea [present study]).

Remarks. The taxonomy of the genus Diaxonella is relatively complicated. According to a review by Berger (2006) on this subspecies, Kaltenbach (see Berger, 2006) described original population that had two frontal rows, a reddish body color, several buccal cirri, and one left marginal row. Berger (2006) considered Keronopsis pseudorubra sensu Kaltenbach in 1960 as a senior synonym of Diaxonella trimarginata sensu Jankowski (1979) which was renamed as a new species and new genus based on Keronopsis rubra sensu Jerka-Dziadosz and Janus (1972), because they misidentified it. Furthermore, he changed the name from Keronopsis pseudorubra to Diaxonella pseudorubra. Berger (2006) also suggested that the genus Diaxonella is monotypic and divided D. pseudorubra into three subspecies, which are distinguished by body color, 
number of midventral pairs, and habitat. However, Shao et al. (2007) did not mention this suggestion of Berger (2006), because their publications overlapped in time.

Consequently, this Korean population of Diaxonella pseudorubra pseudorubra agrees with the original description except in the number of left marginal rows (4 vs. 1) and frontal cirri (3-5 vs. forming bicorona), which were intensively considered by Berger (2006). Additionally, our population agrees well with subsequent redescriptions of Austrian, Chinese, and Polish populations (Jerka-Dziadosz and Janus, 1972; Jankowski, 1979; Oberschmidleitner and Aescht, 1996; Shao et al., 2007). The Korean population differs slightly from the Austrian population of D. pseudorubra pseudorubra in shape of micronuclei (spherical vs. ellipsoidal), number of frontal cirri (3-5 vs. 2-3), canals in the contractile vacuole (absent vs. present), number of pretransverse cirri (2 vs. 3-4), and position of the last midventral cirrus (posterior half vs. posterior) (Oberschmidleitner and Aescht, 1996). Furthermore, the Korean population differs from the Chinese population at the intersecting point (middle vs. posterior) of the undulating membranes, the arrangement of reddish small cortical granules (linearly grouped vs. sparsely scattered), and the shape and diameter of micronuclei (spherical, about $2.5 \mu \mathrm{m}$ vs. ovoid, about $5 \mu \mathrm{m}$ ) (Shao et al., 2007). Moreover, several populations (Europe, Asia, and Africa) of D. pseudorubra pseudorubra have been found in freshwater but this Korean population was recovered from brackish water of an estuarine littoral zone (Berger, 2006).

Family Pseudokeronopsidae Borror \& Wicklow, 1983

Genus Pseudokeronopsis Borror \& Wicklow, 1983

\section{1*Pseudokeronopsis flava (Cohn, 1866)}

(Tables 3, 4, Figs. 4-6)

Oxytricha flava Cohn, 1866: 288.

Holosticha flava Kent, 1882: 769.

Keronopsis rubra Kahl, 1932: 571.

Pseudokeronopsis flava: Wirnsberger et al., 1987: 79; Berger, 2001: 55; Song et al., 2004: 1137; Sun and Song, 2005: 81; Berger, 2006: 940; Song et al., 2006: 272.

Description. General morphology and behavior: Body size $150-210 \times 30-45 \mu \mathrm{m}$, usually about $180 \times 40 \mu \mathrm{m}$, length : width ratio about $5: 1$ in live specimens. Body shape elongated elliptical, both ends narrowly rounded, anterior portion usually concave leftwards (Figs. 4A, 5A), dorsoventrally flattened about $2: 1$ (Fig. 5B). One contractile vacuole located below the mid-body near the left cell margin about $13 \mu \mathrm{m}$ in diameter (Figs. 4A, 5E). Cytoplasm very flexible but not contractile (Fig. 5C), almost yellowish at low magnification. Locomotion usually crawling on substrate, wrapping to change direction (Fig. 5C). Omnivorous feeding (Fig. 5J, K).

Buccal field and oral infraciliature: Adoral zone of membranelles occupies $25-30 \%$ of body length, composed of 44-

Table 3. Morphometric data of Pseudokeronopsis flava

\begin{tabular}{|c|c|c|c|c|c|c|c|c|c|}
\hline Characteristics & Method & Mean & Min & Max & Med & SD & SE & $\mathrm{CV}$ & $\mathrm{n}$ \\
\hline \multirow[t]{2}{*}{ Body length $(\mu \mathrm{m})$} & $L$ & 182.2 & 150 & 208 & 184.7 & 17.3 & 3.9 & 9.5 & 20 \\
\hline & $\mathrm{S}$ & 190.2 & 133 & 268 & 183.9 & 35.4 & 6.5 & 18.6 & 30 \\
\hline \multirow[t]{2}{*}{ Body width $(\mu \mathrm{m})$} & $\mathrm{L}$ & 38.2 & 31 & 44 & 37.6 & 4.0 & 0.9 & 10.4 & 20 \\
\hline & S & 43.9 & 23 & 70 & 44.0 & 15.2 & 2.8 & 34.6 & 30 \\
\hline \multirow[t]{2}{*}{ Body length/Body width } & $\mathrm{L}$ & 4.8 & 4 & 5 & 4.8 & 0.4 & 0.1 & 8.8 & 20 \\
\hline & $\mathrm{S}$ & 4.7 & 3 & 7 & 4.4 & 1.0 & 0.2 & 22.4 & 30 \\
\hline \multirow[t]{2}{*}{ AZM, length $(\mu \mathrm{m})$} & $L$ & 49.3 & 40 & 59 & 49.1 & 5.2 & 1.2 & 10.5 & 20 \\
\hline & $\mathrm{S}$ & 56.0 & 43 & 77 & 57.1 & 8.3 & 1.5 & 14.9 & 30 \\
\hline \multirow[t]{2}{*}{ Body length/length of AZM } & $\mathrm{L}$ & 3.7 & 3 & 5 & 3.6 & 0.5 & 0.1 & 12.9 & 20 \\
\hline & $\mathrm{S}$ & 3.4 & 3 & 5 & 3.3 & 0.4 & 0.1 & 12.0 & 30 \\
\hline AMs, number & $\mathrm{S}$ & 49.0 & 44 & 58 & 48.5 & 3.1 & 0.6 & 6.3 & 30 \\
\hline FC (Bicorona), number & $\mathrm{S}$ & 5.8 & 5 & 7 & 6.0 & 0.6 & 0.1 & 10.0 & 27 \\
\hline BC, number & $\mathrm{S}$ & 1.0 & 1 & 1 & 1.0 & 0.0 & 0.0 & 0.0 & 29 \\
\hline FTC, number & $\mathrm{S}$ & 2.0 & 2 & 3 & 2.0 & 0.2 & 0.0 & 9.8 & 25 \\
\hline TC, number & $\mathrm{S}$ & 3.1 & 2 & 4 & 3.0 & 0.4 & 0.1 & 11.9 & 30 \\
\hline MVC (pair), number & $\mathrm{S}$ & 25.0 & 18 & 33 & 24.5 & 3.5 & 0.7 & 14.2 & 26 \\
\hline LMC, number & $\mathrm{S}$ & 40.8 & 34 & 53 & 40.0 & 5.7 & 1.1 & 13.9 & 27 \\
\hline RMC, number & $\mathrm{S}$ & 48.6 & 40 & 58 & 48.0 & 5.0 & 0.9 & 10.2 & 28 \\
\hline DKs, number & $\mathrm{S}$ & 3.1 & 3 & 4 & 3.0 & 0.4 & 0.1 & 11.2 & 15 \\
\hline
\end{tabular}

Min, minimum; Max, maximum; Med, median; CV, coefficient of variation in \%; $n$, population size; $L$, live specimens; $S$, stained specimens; $A Z M$, adoral zone of membranelles; FC, frontal cirri; Bicorona, FC arranged in arcs forming cirri; BC, buccal cirrus; FTC, frontoterminal cirri; TC, transverse cirri; MVC, midventral cirri; LMC, left marginal cirri; RMC, right marginal cirri; DK, dorsal kineties.

Korean name: ${ }^{1 *}$ 노랑위각모충 
Jung Min Choi, Ji Hye Kim, Mann Kyoon Shin

Table 4. Comparisons of different populations of Pseudokeronopsis flava

\begin{tabular}{|c|c|c|c|}
\hline Characters & Pseudokeronopsis flava & P. flava & P. flava \\
\hline Body length in vivo ( $\mu \mathrm{m})$ & $150-210$ & $120-210$ & $140-350$ \\
\hline Body length $(\mu \mathrm{m})$ & $135-270$ & - & - \\
\hline AMs, number & $44-58$ & $43-59$ & $43-51$ \\
\hline MVC (pairs), number & $18-33$ & $25-32$ & $24-36$ \\
\hline TC, number & $2-4$ & $1-3$ & $3-4$ \\
\hline UM, intersecting point & Mid part of membranes & Absent & Posterior end of membranes \\
\hline Data sources & Present study & Wirnsberger et al., 1987 & Song et al., 2004 \\
\hline
\end{tabular}

All data are based on protargol-impregnated specimens. AMs, adoral membranelles; MVC, midventral cirri; TC, transverse cirri; UM, undulating membranes; EM, endoral membrane; PM, paroral membrane.

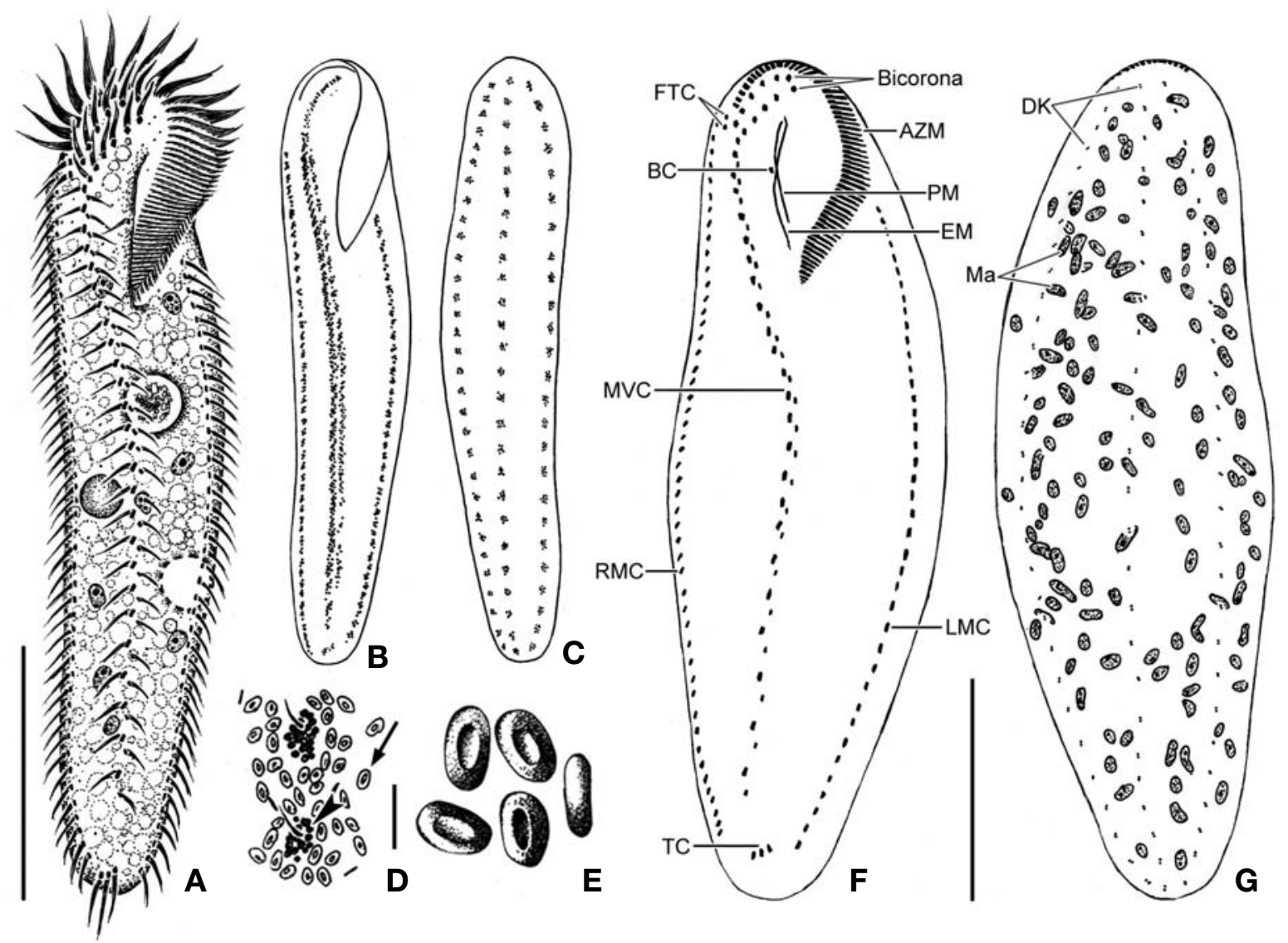

Fig. 4. Pseudokeronopsis flava from live (A-E) and impregnated specimens $(F, G)$. A, Ventral view of a typical individual; $B$, Arrangement of cortical granules on the ventral side; C, Three cortical granular rows on the dorsal side; D, E, Cortical granule groups (arrowhead) and "blood-cell-shaped" granules (arrow) apparatus; F, Somatic and oral infraciliature of the ventral side; G, Three dorsal kineties and nuclear apparatus. AZM, adoral zone of membranelles; BC, buccal cirrus; Bicorona, FC arranged in arcs forming cirri; DK, dorsal kineties; EM, endoral membrane; FTC, frontoterminal cirri; LMC, left marginal cirri; Ma, macronuclear nodules; MVC, midventral cirri; PM, paroral membrane; RMC, right marginal cirri; TC, transverse cirri. Scale bars: $A, G=50 \mu \mathrm{m}, E=2 \mu \mathrm{m}$.

58 adoral membranelles (Figs. 4F, 6A). Buccal area narrow and rather deep. Paroral and endoral membranes slightly curved, intersecting to half of the membranes, endoral longer than paroral, about $35 \mu \mathrm{m}$ in length (Figs. 4F, 6A, D).

Somatic infraciliature: Frontal cirri arranged in two arcs forming bicorona comprising 5-7 cirral pairs, bicorona connect to midventral complex (Fig. 6E). Midventral complex extended to subposterior and consisting of 18-33 cirri; distance between posterior most cirrus of midventral cirri and uppermost transverse cirrus about $20 \mu \mathrm{m}$ (Figs. 4F, 6A). Two or 


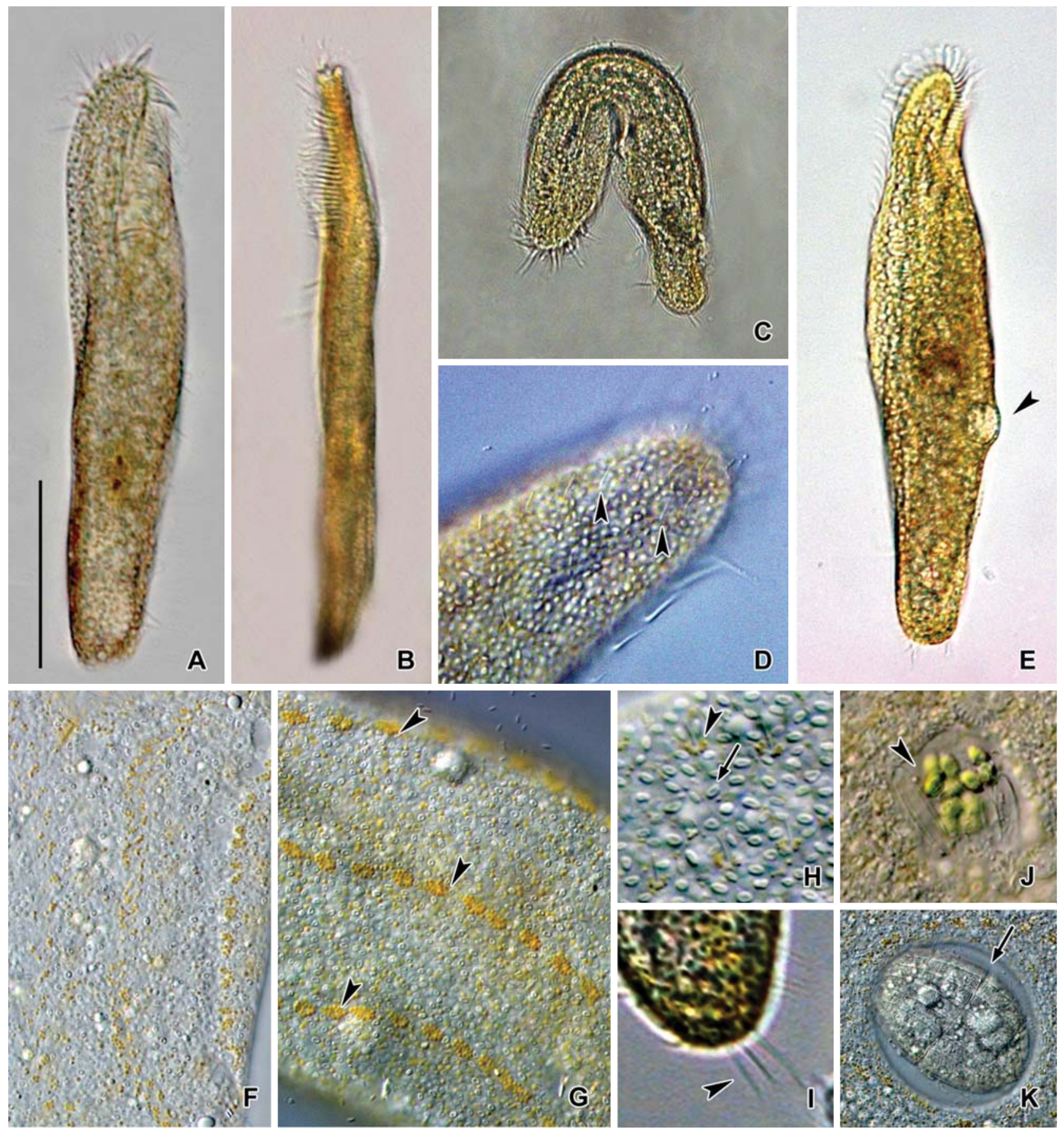

Fig. 5. Photomicrographs of Pseudokeronopsis flava from live specimens. A, Ventral view of a typical individual; B, Flattened lateral view; C, Showing flexible body; D, Dorsal kineties (arrowheads); E, Contractile vacuole (arrowhead); F, Arrangement of cortical granule on ventral side; G, H, Cortical granule groups (arrowheads) and "blood-cell-shaped" granules (arrow) apparatus on dorsal side; I, Three transverse cirri (arrowhead); J, K, Various food vacuoles; J, One kind of Chlorophyta; K, Coleps sp. Scale bar: A=50 $\mu$ m.

three frontoterminal cirri located at the right side of the rightmost bicorona pair (Fig. 6C, E). Buccal cirrus located near the intersecting point of the undulating membranes (Fig. 6D). Two to four transverse cirri located posteriorly and distinctly separated by marginal rows (Figs. 5I, 6F). Right marginal row commenced at level of the down most bicorona cirrus, terminated at the posterior part and comprising 40-58 cirri (Figs. 4F, 6A, E), left marginal row with 34-53 cirri; posterior 


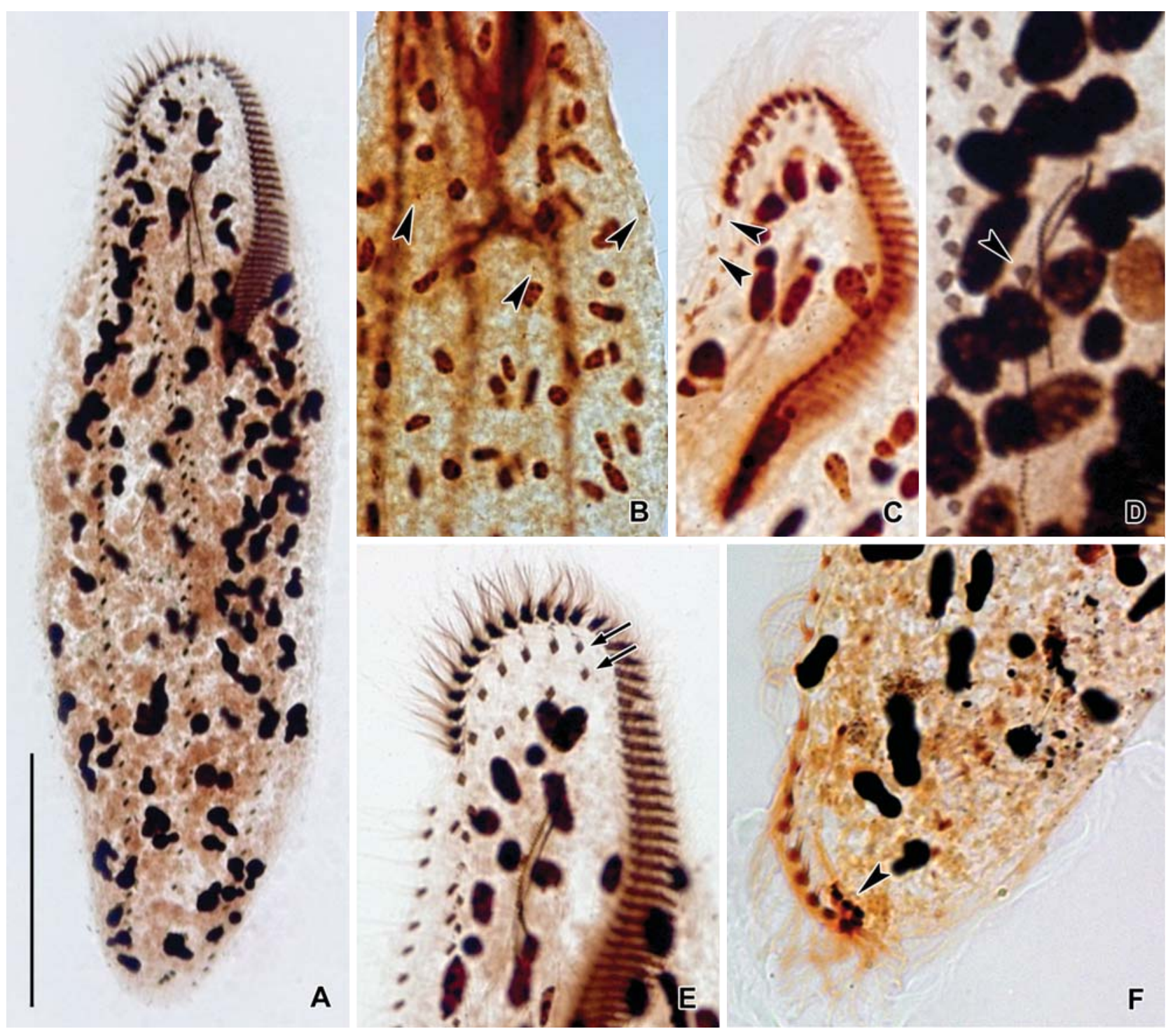

Fig. 6. Photomicrographs of Pseudokeronopsis flava from impregnated specimens. A, Ventral view of a typical individual; $B$, Dorsal kineties (arrowheads); C, Two frontoterminal cirri (arrowheads); D, Buccal cirrus (arrowhead) and undulating membranes; E, Infraciliature of bicorona (arrows); $F$, Three transverse cirri (arrowhead). Scale bar: $A=50 \mu \mathrm{m}$.

ends of marginal rows distinctly separated (Figs. 4F, 6A). Dorsal bristles length 5-10 $\mu \mathrm{m}$ (Fig. 5D), three arranged kineties, dorsal kineties extending to entire dorsal surface (Figs. 4G, 6B).

Cortical granules: Two types of cortical granules present on both sides (Figs. 4D, 5H); yellowish cortical granules forming four rows with cirral rows on ventral side (Figs. 4B, 5F), small groups with dorsal bristles on dorsal side and 0.8-1 $\mu \mathrm{m}$ in diameter (Figs. 4C, 5G, H), colorless cortical granules shaped ellipsoidal and "blood-cell-shaped" under both cortex and about $2 \times 1.5 \mu \mathrm{m}$ in size (Fig. $5 \mathrm{G}, \mathrm{H}$ ).

Nuclear apparatus: $70-100$ ovoid to ellipsoidal macronuclear nodules, size 5-10 $\mu \mathrm{m}$ long in protargol-impregnated specimens. Micronucleus inconspicuous, about $3 \mu \mathrm{m}$ in diameter (Figs. 4G, 6A).

Distribution. Europe (England, France, Denmark, Germany, Italy, and Poland), North America (USA), and Asia (China and Korea [present study]).

Remarks. The Korean population of Pseudokeronopsis flava closely matched the original and subsequent redescriptions. However, the Korean population differs from the other populations in the pattern of undulating membranes. The undulating membranes of the Korean population usually have one intersecting point at the mid part, whereas those of the Chinese 
population have no intersecting point at the mid part. The length of the endoral membrane is usually longer than that of the paroral in the Korean population, whereas that of both membranes is equal in the Chinese population. However, the lengths of the endoral and paroral membranes of the Danish population are similar to those of the Korean population (Cohn, 1866; Song et al., 2004, 2006; Sun and Song, 2005; Berger, 2006). The size of the pigment granules is slightly different in the Korean and Chinese populations (0.8-1 $\mu \mathrm{m}$ vs. $0.5 \mu \mathrm{m})$ (Song et al., 2004, 2006).

Closely-related species of Pseudokeronopsis flava are $P$. carnea, P. flavicans, and P. rubra, but they can be distinguished from each other as follows. Pseudokeronopsis flava is different from $P$. carnea in terms of pigment granule color (yellow vs. red), number of bicorona (5-7 vs. 9-11), number of midventral cirri (ca. 25 vs. ca. 40), number of transverse cirri (2-4 vs. 8-9), number of dorsal kineties (3 vs. 7-8), and number of adoral membranelles (ca. 50 vs. ca. 70). Pseudokeronopsis flava is different from $P$. flavicans in posterior body shape (slightly narrow vs. distinctly narrow), position of the contractile vacuole (posterior half vs. anterior half), number of dorsal kineties ( 3 vs. 5), and the gap between the posterior of the midventral row and transverse cirri (wide vs. narrow). Pseudokeronopsis flava is different from $P$. rubra in pigment granule color (yellow vs. red) and number of dorsal kineties (3 vs. usually 4-6) (Song et al., 2002, 2004, 2006, Berger, 2006).

\section{ACKNOWLEDGEMENTS}

This study was supported by the grant from the National Research Foundation of Korea Grant funded by the Korea Government (No. 2009-0077263), and "The Survey of Korean Indigenous Species" supported by the National Institute of Biological Resources (NIBR) of Korea.

\section{REFERENCES}

Berger H, 2001. Catalogue of ciliate names 1. Hypotrichs. Verlag Helmut Berger, Salzburg, pp. 1-206.

Berger H, 2006. Monograph of the Urostyloidea (Ciliophora, Hypotricha). Springer Publishers, Dordrecht, pp. 1-1303.

Borror AC, Wicklow BJ, 1983. The suborder Urostylina Jankowski (Ciliophora, Hypotrichida): morphology, systematics and identification of species. Acta Protozoologica, 22:97-126.

Bütschli O, 1889. Protozoa. III. Abtheilung: Infusoria und System der Radiolaria. In: Klassen und Ordnungen des ThierReichs, wissenschaftlich dargestellt in Wort und Bild, Vol. 1 (Ed., Bronn HG). C.F. Winter'sche Verlagsjandlung, Leipzig and Heidelberg, pp. 1585-2035.
Cohn F, 1866. Neue Infusorien im Seeaquarium. Zeitschrift für Wissenschaftliche Zoologie, 16:253-302.

Corliss JO, 1979. The ciliated protozoa: characterization, classification and guide to the literature. Pergamon Press, London and New York, pp. 1-455.

Foissner W, 1987. Miscellanea nomenclatorica ciliatea (Protozoa; Ciliophora). Archiv für Protistenkunde, 133:217-235.

Foissner W, 1992. Protargol methods. In: Protocols in protozoology (Eds., Lee JJ, Soldo AT). The Society of Protozoologists, Allen Press, Lawrence, KS, p. C 6.1-C 6.8.

Jankowski AW, 1979. Revision of the order Hypotrichida Stein, 1859. Generic catalogue, phylogeny, taxonomy. Trudy Zoologicheskogo Instituta Akademii Nauk SSSR, 86:46-85.

Jerka-Dziadosz M, Janus I, 1972. Localization of primordia during cortical development in Keronopsis rubra (Ehrbg., 1838) (Hypotrichida). Acta Protozoologica, 10:249-262.

Kahl A, 1932. Urtiere oder Protozoa. I: Wimpertiere oder Ciliata (Infusoria), 3. Spirotricha. Die Tierwelt Deutschlands, 25:399650.

Kent WS, 1882. A manual of the infusoria: including a description of all known flagellate, ciliate and tentaculiferous protozoa, British and foreign, and an account of the organization and affinities of the sponges. Vol. 2. David Bogue, London, pp. 721-913.

Lynn DH, 2008. The ciliated protozoa: characterization, classification, and guide to the literature. 3rd ed. Springer Publishers, New York, pp. 1-605.

Lynn DH, Small EB, 2002. Phylum Ciliophora. In: An illustrated guide to the Protozoa: organisms traditionally referred to as protozoa, or newly discovered groups, Vol. 1 (Eds., Lee JJK, Leedale GF, Bradbury PC). 2nd ed. Society of Protozoologists, Lawrence, pp. 371-656.

Oberschmidleitner R, Aescht E, 1996. Taxonomische Untersuchungen über einige Ciliaten (Ciliophora, Protozoa) aus Belebtschlämmen oberösterreichischer Kläranlagen. Beiträge zur Naturkunde Oberösterreichs, 4:3-30.

Shao C, Song W, Li L, Warren A, Hu X, 2007. Morphological and morphogenetic redescriptions of the stichotrich ciliate Diaxonella trimarginata Jankowski, 1979 (Ciliophora, Stichotrichia, Urostylida). Acta Protozoologica, 46:25-39.

Song W, Sun P, Ji D, 2004. Redefinition of the yellow hypotrichous ciliate, Pseudokeronopsis flava (Hypotrichida: Ciliophora). Journal of the Marine Biological Association of the United Kingdom, 84:1137-1142.

Song W, Warren A, Roberts D, Wilbert N, Li L, Sun P, Hu X, $\mathrm{Ma} H, 2006$. Comparison and redefinition of four marine, coloured Pseudokeronopsis spp. (Ciliophora: Hypotrichida), with emphasis on their living morphology. Acta Protozoologica, 45:271-287.

Song W, Wilbert N, Warren A, 2002. New contribution to the morphology and taxonomy of four marine hypotrichous ciliates from Qingdao, China (Protozoa: Ciliophora). Acta Protozoologica, 41:145-162.

Sun P, Song WB, 2005. Morphogenesis of the marine ciliate Pseudokeronopsis flava (Cohn, 1866) Wirnsberger et al., 
1987 (Protozoa: Ciliophora: Hypotrichida). Acta Zoologica Sinica, 51:81-88.

Wilbert N, 1975. Eine Verbesserte Technik der Protargolimpragnation für Ciliaten. Mikrokosmos, 64:171-179.

Wirnsberger E, Larsen HF, Uhlig G, 1987. Rediagnoses of closely related pigmented marine species of the genus Pseudokero- nopsis (Ciliophora, Hypotrichida). European Journal of Protistology, 23:76-88.
Received September 27, 2011
Revised November 8, 2011 Accepted November 16, 2011 